\title{
Evaluation of AVI and DRASTIC Methods for Groundwater Vulnerability Mapping
}

\author{
G. K. Anornu (Corresponding author) \\ Department of Civil Engineering, \\ Kwame Nkrumah University of Science and Technology (KNUST), Private Mail Bag \\ University Post Office, Kumasi, Ghana
}

Tel: 233-244-882-912Ｅ-mail: anoprof@hotmail.com

Amos T. Kabo-bah

Department of Energy and Environmental Engineering, University of Energy and Natural Resources (UENR), P.O. Box 214, Sunyani, Ghana

Tel: 233-543-859-721Ｅ-mail: amos.kabobah@uenr.edu.gh

Received: August 8, 2013 Accepted: August 20, $2013 \quad$ Published: December 1, 2013

doi:10.5296/jee.v4i2.4961ＵRL: http://dx.doi.org/10.5296/jee.v4i2.4961

\begin{abstract}
The Densu River Basin is one of the important basins in Ghana. A large number of residents in this basin are dependent on groundwater for their livelihood. However, with the growing population, urbanization and impact of climate change, it is imperative to develop ways to protect and manage the limited groundwater resource that is supporting the communities. As a result, this paper assessed the groundwater vulnerability by comparing two methods - the Depth to water, net Recharge, Aquifer media, Soil media, Topography, Impact of the vadose zone, and hydraulic Conductivity DRASTIC an the Aquifer Vulnerability Index (AVI). The results show that DRASTIC is more precise and representative of the groundwater vulnerability in the basin. The AVI statistically show a relatively lower risks compared to DRASTIC. It is recommended, AVI which is oversimplified may be useful for larger basins.
\end{abstract}

Keywords: Hydraulic Conductivity, Vadoze zone, Aquifer media 


\section{Introduction}

One of the main drivers to achieve the United Nations Millennium Development Goals (UN MDG) and end poverty in developing countries is the access to reliable potable water. This goal by the UN, continues to be the number one challenge to achieve by 2015 . This is so because of the natural complexity of water existence and the current likelihood impacts from climate change. In most developing countries, groundwater stands as the most reliable, clean and safe water for household use(Gleick, 1993; Oki \& Kanae, 2006). Yet, the rapid growing of population, urbanization, indiscriminate disposal of waste, siting of public toilets and septic tanks stand a high potential at implicating the usefulness of this vital resource groundwater(Foster, 1990).

In sub-Saharan Africa, groundwater is a vital resource to support the provision of potable water, watering of animals and dry season farming. Estimates are that, about $50 \%$ of sub-region relies on groundwater for their daily livelihood (Braune \& Xu, 2010). In Ghana, groundwater continues to be the main potable water supply for a lot of people in the urban and rural settlements. Over the years, urbanization and industrial activities in the Densu River Basin have been increasing due to the country's economic development. From the Weija reservoir, which is on the Densu river, water is supplied to about half the population of the Accra Metropolis (WRC, 2012). The Water Resources Commission (WRC) of Ghana noted that there are inherent practices in the basin that have negative influences on the water quality in this basin. These include farming along the banks of the Densu River, use of agrochemicals for farming and fishing, poor infrastructure development, indiscriminate disposal of solid and liquid wastes from authorities and illegal mining activities (WRC, 2012). According to the same report, it is estimated that over fifty licensed well drillers and raw water users have signed up with the commission for groundwater development and use.

In view of this, the natural understanding of the vulnerable character of groundwater in the Densu River Basin is very vital for planning, decision making and policy drafting to protect and safeguard it.

Several methods have been developed by engineers and scientists in the last decade to monitor and map out the vulnerability of groundwater in parts of the world. Out of the lots, two methods (DRASTIC and AVI methods) have been widely accepted to meet the needs of most countries globally. The simple difference between the two is that, DRASTIC requires more data to make a decision on the aquifer vulnerability while AVI requires a few to do the same work. The question therefore is which of these methods is most suitable? And what makes one suitable for particular watershed and under what conditions could either of these be considered useful? To provide baseline information, this paper evaluated the two methods for the Densu River Basin of Ghana. The paper seeks to provide the core strengths and weakness of each of these methods and by so doing, anticipates a contribution towards an improved monitoring and evaluation of groundwater vulnerability in Ghana and the sub-region. 


\section{Macrothink}

\section{Materials and Methods}

\subsection{Data Sources}

The data in table 1 were used to estimate the groundwater vulnerability using the DRASTIC and AVI method. The parameters (depth of water, net recharge, aquifer media, soil media, slope, impact of the vadose zone and hydraulic conductivity) were determined according to previous studies using the open and free source Geographic Information Systems (GIS) software - ILWIS Open.

Table 1. Parameters required by DRASTIC and AVI

\begin{tabular}{lll}
\hline Parameter & Data source & Purpose \\
\hline $\begin{array}{l}\text { Depth of water } \\
\text { Net recharge }\end{array}$ & $\begin{array}{l}\text { Pumping test data } \\
\text { TAMSAT rainfall data \& annual ET } \\
\text { estimation }\end{array}$ & $\begin{array}{l}\text { AVI, DRASTIC } \\
\text { DRuifer media }\end{array}$ \\
$\begin{array}{l}\text { Soil media } \\
\text { Slope }\end{array}$ & Soil map, Ghana \\
Impact of vadose zone & DRASTIC \\
Hydraulic & SRTM 90m DEM & DRASTIC \\
conductivity & Algorithm developed by (Luo, & DRASTIC \\
& Grudzinski, \& Pederson, 2011; Luo \& & DRASTIC \\
\hline
\end{tabular}

\subsection{The DRASTIC Method}

The DRASTIC is an acronym standing for seven parameters - Depth to water(D), Net recharge(R), Aquifer media(A), Soil media(S), Topography(T), Impact of the vadose zone (I), and hydraulic Conductivity of the aquifer(C). A detailed explanation of each of these terms is fully documented in (Aller, Lehr, Petty, \& Bennett, 1987). The DRASTIC method is given as:

$$
\text { DRASTIC Index }=D_{r} D_{w}+R_{r} R_{W}+A_{r} A_{W}+S_{r} S_{W}+T_{r} T_{W}+I_{r} I_{W}+C_{r} C_{W} \text {, }
$$

Where; Subscripts $r$ is rating and $w$ is the weight

DRASTIC assigns weights to each of the seven parameters mentioned above (See Table 2)

Table 2. DRASTIC assigned weights

\begin{tabular}{lc}
\hline Parameter & DRASTIC weights \\
\hline Depth of water & 5 \\
Net recharge & 4 \\
Aquifer media & 3 \\
Soil media & 2 \\
Slope & 1 \\
Impact of vadose zone & 5 \\
Hydraulic conductivity & 3 \\
\hline
\end{tabular}

Source: Aller et al. (1987) 
Over the years the DRASTIC method has received considerable attention in the US, Canada and around the world (Anornu, Kabo-bah, \& Anim-Gyampo, 2012; Ducci \& Sellerino, 2013; Panagopoulos, Antonakos, \& Lambrakis, 2006; Rahman, 2008; Sener, Sener, \& Davraz, 2009). The advantage of DRASTIC is in the selection of relative weights, however, the selection of such weights creates some redundancies in the parameters. Some of the reason for this is that, some parameters are dependent and related, as for example, the soil media and vadose zone parameters overlap and the hydraulic conductivity is totally redundant since it is derived completely from aquifer properties(Stempvoort, Ewert, \& Wassenaar, 1993). The other challenge with the DRASTIC is that, it requires essential data called net recharge. This in practice is very difficult to quantify and scale it according to geographic areas(Keller, van der Kamp, \& Cherry, 1988). For this particular research, the study employed the methods and results obtained in previous study (See Table 3) on the Densu River Basin (Anornu, et al., 2012).

Table 3. DRASTIC ratings for Densu River Basin

\begin{tabular}{lc}
\hline Parameter & DRASTIC Rating \\
\hline Depth of water & 10 \\
Net recharge & $6-9$ \\
Aquifer media & $5-9$ \\
Soil media & $1-7$ \\
Slope & $1-10$ \\
Impact of vadose zone & $3-8$ \\
Hydraulic conductivity & 1 \\
\hline
\end{tabular}

\subsection{The Aquifer Vulnerability Index (AVI) Method}

The AVI method was developed to simplify the approach of estimating the vulnerability of an aquifer (Van Stempvoort, Ewert, \& Wassenaar, 1993).This method measures groundwater vulnerability using two physical parameters - the thickness (d) of each sedimentary rock above the uppermost saturated aquifer surface and estimated hydraulic conductivity (K). The two physical parameters, $\mathrm{d}$ and $\mathrm{K}$ are used to compute the hydraulic resistance (c) as in:

$$
c=\sum_{i=1}^{i} \frac{d_{i}}{K_{i}}
$$

The hydraulic resistance which has a unit of time, is the theoretical factor used to describe the resistance of an aquitard to vertical flow (Kruseman \& Ridder, 1990). This time factor indicates the estimated travel time for water to move by advection through the porous media above the saturated aquifer surface. The calculated hydraulic resistance is used to generate iso-resistance contour maps (See Figure 1). This is then related to the Aquifer Vulnerability Index as in Table 2. The hydraulic resistance is shown in Figure 2. This was to ensure that the comparison of the two methods was based on fair judgment of the same data source, assumption and computational deficiencies. 


\section{Macrothink}

Table 2. Relationship of AVI to hydraulic resistance(c)

\begin{tabular}{|c|c|c|}
\hline $\begin{array}{l}\text { Hydraulic } \\
\text { (c) }\end{array}$ & $\log (c)$ & Vulnerability Index \\
\hline 0 to $10 \mathrm{yr}$ & $<1$ & Extremely high \\
\hline 10 to $100 \mathrm{yr}$ & 2 & High \\
\hline 100 to $1,000 \mathrm{yr}$ & 3 & Moderate \\
\hline 1,000 to $10,000 \mathrm{yr}$ & 4 & Low \\
\hline$>10,000 \mathrm{yr}$ & $>5$ & Extremely Low \\
\hline
\end{tabular}

Van Stempvoort et al. (1993) documented the exact interpretation of each of these physical parameters. It is argued from this research that, the consideration of these two physical parameters are approximately adequate to determine the aquifer vulnerability.

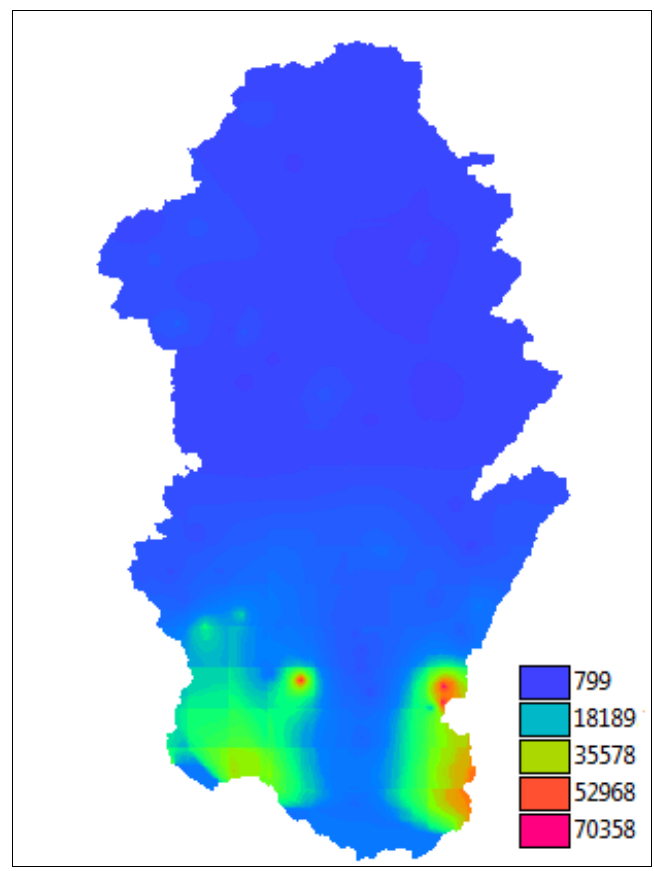

Figure 1. AVI Hydraulic resistance (c) 


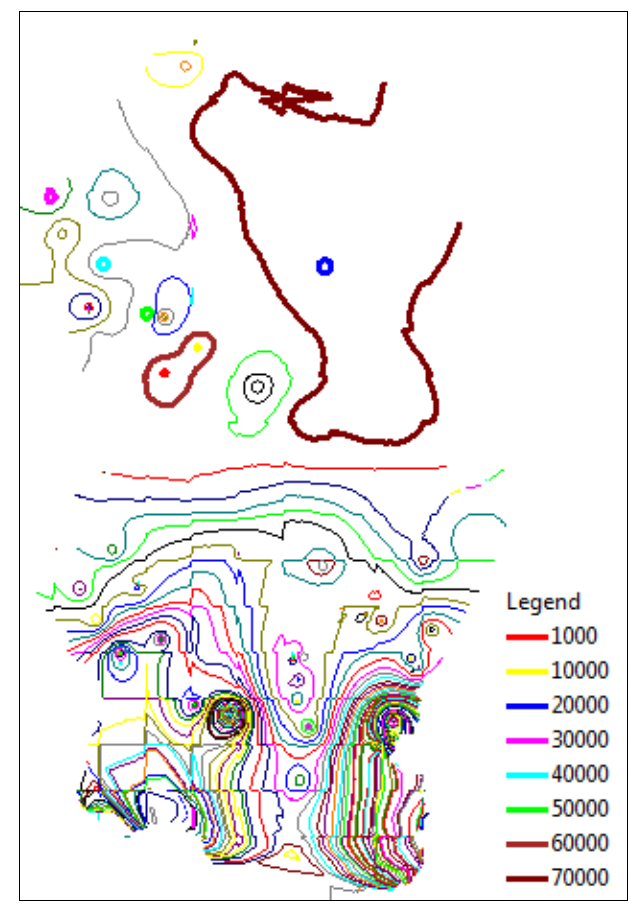

Figure 2. AVI iso-resistance map

\section{Results and Discussion}

The indices computed by DRASTIC and AVI allow for easy interpretation of the results and also for use by non-technically decision makers. In this paper the question has been which of the methods may be most suitable for studying the important basin which is currently challenged by rapid population growth and inappropriate environmental practices. The results of the final maps created with DRASTIC and AVI are shown in Figure 2. The DRASTIC index shows a variation values between [114-120] for low-risk, [120-129] for medium-risk and higher than [130] for high risk zones. The high-risk, medium-risk and low-risk areas represent about 47\% (NNW, NSW, NNE), 43\% (NNE, NNW and NSW) and 10\% (middle belt NN-S) respectively (Anornu, et al., 2012). The AVI index shows a variation of [2-3] for moderately high, [3-4] for Moderately Low and [above 4] for Extremely Low. The AVI zones represent $0.1 \%, 76.6 \%$ and $23.4 \%$ respectively for Moderately High, Moderately Low and Extremely Low zones. There is a significant variation looking at the representative scales of each of the methods. The DRASTIC method suggests a higher chance of vulnerability of the aquifer and hence calls for immediate actions to remedy the situation in the basin. However the AVI suggests moderately low conditions as to aquifer vulnerability. The reason for this variation is that, the AVI do not take into account following critical issues which are rapidly changing as a result of urbanization and human activity in the basin. This issues were originally noted by the authors of AVI (Van Stempvoort, et al., 1993)that :

- Parameters such as climate, hydraulic gradient, porosity and water content of the porous media, and sorptive or reactive properties of the layers which are contaminant-specific were ignored;

- The method considers only nearest to surface aquifers and assumes homogeneity with 
aquifer properties and hence aquifer water quality in effect is ignored.

- The method does not take into consideration parameters such as topography and aquifer media.

It is obvious that though DRASTIC seems to be over-parametised with the number of datasets, it gives a reasonable judgment of the basin conditions as at present. This is because other studies in the basin have indicated that there exists a relative high potential of the groundwater resources in the basin(Dickson Adomako, Gibrilla, Akiti, Fianko, \& Maloszewski, 2011; D Adomako, Osae, Akiti, Faye, \& Maloszewski, 2011; Fianko, et al., 2010) and that the groundwater was highly susceptible due to the geographical conditions and impact from human activity. This qualitatively describes the groundwater bearing rock as vulnerable to the high human activity in this basin. The DRASTIC represents more informed decision tool for assessing groundwater vulnerability in the basin. The assessment of vulnerability is a characteristic in groundwater that cannot be directly obtained from measurements in the field and hence is more or less a concept to show that some lands are more susceptible to groundwater contamination in relation to others (Vrba \& Zaporozec, 1994). Vulnerability therefore do not intend to mean exact groundwater quality. Studies from previous researches reveal that DRASTIC provides more precise and flexibility for detailed studies (Gogu \& Dassargues, 2000). The oversimplification of the AVI on groundwater parameters will be useful in relatively large basins and may be considered for quick reference purposes but for more detailed and rigorous understanding of the groundwater vulnerability, the DRASTIC is preferred.

It must however be noted that both DRASTIC and AVI are qualitative subjective techniques to inform planners, engineers, environmentalist, policy makers and civil society in the basin about the potential of groundwater pollution. The methods can be considered as basically informative especially in the area of ensuring and practice of Integrated Water Resources Management in the Basin (IWRM). Therefore, the used of DRASTIC and AVI are important tools to support IWRM implementation in the Densu River Basin. 


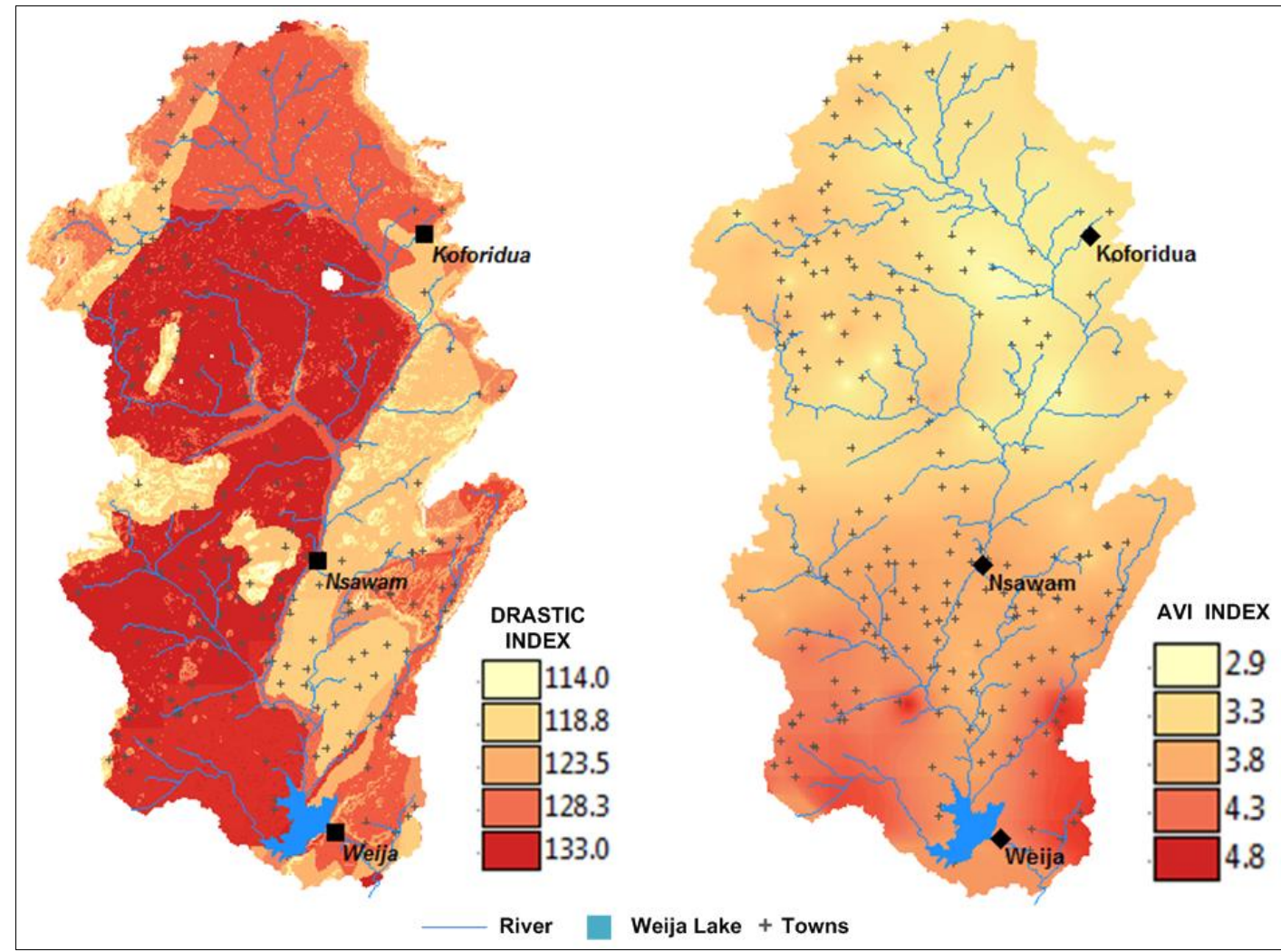

Figure 3. Drastic and AVI indices comparison in the Densu River Basin

\section{Conclusion}

Groundwater is a vital resource and communities in the Densu River Basin are dependent on it for potable use and commercial purposes. This study examined the extent of groundwater vulnerability in the basin to foretell planner and decision makers as to the likely strategies that need to be put to safeguard potential groundwater depletion. The paper therefore compared two methods - DRASTIC and AVI which are widely used indices for mapping groundwater vulnerability. The DRASTIC method is complexity and data intensive while the AVI is oversimplified and hence require less data. The study revealed that the DRASTIC provided better approximation of the groundwater vulnerability conditions compared to the AVI. The difference has been the short shortfalls of the AVI to incorporate conditions e.g. hydraulic gradient and soil media. Notwithstanding, the two methods provide an informative mapping tool that can be used for decision makers to safeguard the scarce groundwater resources in the basin.

\section{Acknowledgement}

The authors wish to acknowledge the kind contributions from Gloria Appiah-Sefah at the Hohai University for her review and comments.

\section{References}

Adomako, D., Gibrilla, A., Akiti, T. T., Fianko, R., \& Maloszewski, P. (2011). Hydrogeochemical Evolution and Groundwater Flow in the Densu River Basin, Ghana. 
Journal of Water Resource and Protection, 3(7), 548-561.

Adomako, D., Osae, S., Akiti, T., Faye, S., \& Maloszewski, P. (2011). Geochemical and isotopic studies of groundwater conditions in the Densu River Basin of Ghana. Environmental Earth Sciences, 62(5), 1071-1084.

Aller, L., Lehr, J. H., Petty, R., \& Bennett, T. (1987). Drastic-a standardized system to evaluate groundwater pollution potential using hydrogeologic setting. Journal of the Geological Society of India, 29(1), 23-37.

Anornu, G., Kabo-bah, A. T., \& Anim-Gyampo, M. (2012). Evaluation of Groundwater Vulnerability in the Densu River Basin of Ghana. American Journal of Human Ecology, 1(3), 79-86.

Braune, E., \& Xu, Y. (2010). The Role of Ground Water in Sub-Saharan Africa. Ground water, 48(2), 229-238. http://dx.doi.org/10.1111/j.1745-6584.2009.00557.x

Ducci, D., \& Sellerino, M. (2013). Vulnerability mapping of groundwater contamination based on 3D lithostratigraphical models of porous aquifers. Science of The Total Environment, 447, 315-322. http://dx.doi.org/10.1016/j.scitotenv.2012.12.090

Fianko, J. R., Adomako, D., Osae, S., Ganyaglo, S., Kortatsi, B. K., \& Tay, C. K., et al. (2010). The hydrochemistry of groundwater in the Densu River Basin, Ghana. Environmental monitoring and assessment, 167(1), 663-674.

Foster, S. S. (1990). Impacts of urbanization on groundwater. Hydrological processes and water management in urban areas. Wallingford, UK, International Association of Hydrological Sciences Association Internationale des Sciences Hydrologiques (IAHS Pub. No. 198).

Gleick, P. H. (1993). Water and conflict: Fresh water resources and international security. International Security, 18(1), 79-112.

Gogu, R., \& Dassargues, A. (2000). Current trends and future challenges in groundwater vulnerability assessment using overlay and index methods. Environmental geology, 39(6), 549-559.

Keller, C. K., van der Kamp, G., \& Cherry, J. A. (1988). Hydrogeology of Two Saskatchewan Tills. Fractures, Bulk Permeability, and Spatial Variability of Downward Flow. Journal of Hydrology, 101, 97-121.

Kruseman, G. P., \& Ridder, N. A. (1990). Analysis and evaluation of pumping test data. ILRI publication, 47.

Luo, W., Grudzinski, B., \& Pederson, D. (2011). Estimating hydraulic conductivity for the Martian subsurface based on drainage patterns -A case study in the Mare Tyrrhenum Quadrangle. Geomorphology, $\quad$ 125(3), 414-420. http://dx.doi.org/10.1016/j.geomorph.2010.10.018

Luo, W., \& Pederson, D. T. (2012). Hydraulic conductivity of the High Plains Aquifer 


\section{Macrothink}

re-evaluated using surface drainage patterns. Geophysical Research Letters, 39(2), L02402. DOI: 10.1029/2011GL050200

Oki, T., \& Kanae, S. (2006). Global hydrological cycles and world water resources. Science, 313(5790), 1068-1072. http://dx.doi.org/10.1126/science.1128845

Panagopoulos, G., Antonakos, A., \& Lambrakis, N. (2006). Optimization of the DRASTIC method for groundwater vulnerability assessment via the use of simple statistical methods and GIS. Hydrogeology Journal, 14(6), 894-911.

Rahman, A. (2008). A GIS based DRASTIC model for assessing groundwater vulnerability in shallow aquifer in Aligarh, India. Applied Geography, 28(1), 32-53. http://dx.doi.org/10.1016/j.apgeog.2007.07.008

Sener, E., Sener, S., \& Davraz, A. (2009). Assessment of aquifer vulnerability based on GIS and DRASTIC methods: a case study of the Senirkent-Uluborlu Basin (Isparta, Turkey). Hydrogeology Journal, 17(8), 2023-2035.

Stempvoort, D. V., Ewert, L., \& Wassenaar, L. (1993). Aquifer Vulnerability Index: a GIS compatible method for groundwater vulnerability mapping. Canadian Water Resources Journal, 18(1).

Van Stempvoort, D., Ewert, L., \& Wassenaar, L. (1993). Aquifer vulnerability index: a GIS-compatible method for groundwater vulnerability mapping. Canadian Water Resources Journal, 18(1), 25-37. http://dx.doi.org/10.4296/cwrj1801025

Vrba, J., \& Zaporozec, A. (1994). Guidebook on mapping groundwater vulnerability. International contributions to hydrogeology, 16.

WRC (2012). Basin - Densu Retrieved February 22, 2013, from http://wrc-gh.org/en/basins/15/densu

\section{Copyright Disclaimer}

Copyright reserved by the author(s).

This article is an open-access article distributed under the terms and conditions of the Creative Commons Attribution license (http://creativecommons.org/licenses/by/3.0/). 